Transportation Research Forum

Industry Issue Paper: Refrigerated Food Transport from Canada to Mexico: Cold Chain Challenges Author(s): Barry E. Prentice and Ron McLachlin

Source: Journal of the Transportation Research Forum, Vol. 47, No. 2 (Summer 2008), pp. 119-131

Published by: Transportation Research Forum

Stable URL: http://www.trforum.org/journal

The Transportation Research Forum, founded in 1958, is an independent, nonprofit organization of transportation professionals who conduct, use, and benefit from research. Its purpose is to provide an impartial meeting ground for carriers, shippers, government officials, consultants, university researchers, suppliers, and others seeking exchange of information and ideas related to both passenger and freight transportation. More information on the Transportation Research Forum can be found on the Web at www.trforum.org. 


\title{
Refrigerated Food Transport from Canada to Mexico: Cold Chain Challenges
}

\author{
by Barry E. Prentice and Ron McLachlin
}

Qualitative research methods are used to examine the status of the "cold chain," which serves the Mexican market for Canadian food products. A brief synopsis of Canadian food exports to Mexico is presented to establish the demand for refrigerated transport. Subsequently, the supply of refrigerated transport is considered in terms of modal choice and routes from Canada to Mexico. This is followed by a narrative of cold chain challenges identified by industry respondents. The conclusion points to some policy issues for consideration.

\section{INTRODUCTION}

The Mexican demand for value-added food imports has grown rapidly with the introduction of supermarket food distribution systems. Most value-added food products require climate controlled transport and storage, which is referred to as the "cold chain." A continuous cold chain is necessary to maintain quality and extend the shelf-life of perishable products. Mexican supermarkets completed the critical link in the cold chain that enables value-added food products from Canada and the United States to be exported to this market.

The Mexican food import market is large, diverse and accessible, but efficient logistics and transportation are critical to the competitiveness of food exporters. U.S. food suppliers to Mexico have a cost advantage based on their geographic proximity. Canadian food exporters face logistics costs associated with two border crossings. Goods destined for Mexico must either be cleared first at the U.S. Customs, or cross the United States in-bond before negotiating Mexican border customs and other inspections. The in-bond system allows cargo to be transported from the Canada-U.S. arrival port, without appraisal or payment of duties, to another U.S. port for official entry into U.S. commerce or for exportation - in this case, to Mexico.

The purpose of this article is to provide an overview of the cold chain logistics involved in Canadian food exporters serving Mexico. The analysis draws upon a larger study that involved extensive fieldwork interviews with exporters, carriers, importers and intermediaries that are active in the refrigerated product movements to Mexico (Prentice and McLachlin 2007).

\section{METHODOLOGY}

Structured interviews were conducted with managers of refrigerated food export/import trade and transport/logistics firms. A qualitative methodology was employed with members of the cold chain to identify issues, problems and constraints. Interviews were recorded with managers located in various regions of Canada, as well as Mexico, mostly at Mexico City locations. The common thread was that each organization was involved in the logistics of the export or import of perishable food products from Canada to Mexico.

The specific qualitative method used is a combination of grounded research (Locke 2001; Strauss and Corbin 1998) and case-based research (Eisenhardt 1989, Yin 2003). These approaches are particularly appropriate for managerial research and work well together. Case methods concern the objects of a study and grounded methods concern the handling and interpretation of data within a case (Locke 2001). 
Grounded procedures follow Strauss and Corbin (1998), who propose coding interview data via open, axial and selective coding. Open coding refers to generating categories, axial coding to positioning categories within a theoretical model, and selective coding to further selection of the categories to a manageable number. According to Yin (2003), case-based approaches are appropriate under certain conditions, compared to other forms of research (e.g., experiments, surveys, archival analysis and histories). The appropriate conditions are (1) the research questions are "how," "why," or certain types of "what" questions, (2) the researcher has no control over behavioral events, and (3) the focus of the research is on contemporary events. These conditions are met for this research, as the larger study attempts to understand the issues, problems and constraints of exporting (or importing) perishable food products from Canada to Mexico. Thus, a case-based methodology is more appropriate than conducting a scientific survey, which is better-suited to gathering frequency data about specific questions.

Contact lists were provided by Agriculture Canada and the Canadian Embassy in Mexico. To date, 19 interviews have been conducted. This is an adequate number for case research, which does not follow statistical sampling logic (Yin 2003). The typical interview with a manager in a supply chain position lasted at least one hour and consisted mainly of open ended questions. Each was recorded, transcribed and imported into software (NVivo7) designed to aid in the coding and analysis of qualitative data. Descriptive data were also obtained during the interviews on various transport costs, shipping times and the routing of shipments. These data are indicative of service, but they can not be considered representative in a statistical sense.

The next section presents a snapshot of the Canadian food exports to Mexico and the demand for refrigerated transport. Subsequently, the supply of refrigerated transport is considered in terms of modal choice and routes. This is followed by a narrative of cold chain challenges identified by the respondents. The conclusion points to some policy issues for consideration.

\section{OVERVIEW OF CANADA'S FOOD EXPORTS TO MEXICO}

In 2006 the Mexican food import market was estimated to be the $13^{\text {th }}$ largest in the world, with imports of $\$ 18$ billion. The United States is the largest food exporter to Mexico and accounts for $70 \%$ of all food imports. Canada's share of the Mexican food import market was approximately $\$ 1.6$ billion, or 9\% (Agriculture and Agri-food Canada 2006).

Food product exports can be divided into three groups: bulk commodities, intermediate goods and consumer products. Figure 1 presents the values of each product category exported to Mexico from Canada as reported by Statistics Canada. In 2007 bulk commodities account for $56 \%$ of total agri-food export value, intermediate goods represent $17 \%$ of sales, and consumer goods earn $27 \%$ of total agri-food export revenues with Mexico.

Bulk commodities are mainly grains and oilseeds. These commodities have few value-added services except cleaning, classification and storage. Intermediate goods include such diverse products as breeding stock, tobacco and raw hides. Intermediate value-added products are used as inputs to achieve higher value-added finished goods in Mexico. Consumer goods are generally ready to consume and contain the most value-added services.

The shares of these product classifications change from year to year. Since 2003 the share of intermediate goods has been growing steadily relative to consumer goods, but this time period is too short to identify trends. For example, significant increases in tobacco exports occurred in 2006 and 2007. This one product increased intermediate goods exports by $75 \%$. At the same time, consumer product exports are recovering from the impact of Bovine Spongiform Encephalopathy (BSE), or mad cow disease, which cut off beef exports to Mexico. These data show up after 2004. Such events illustrate the sensitivity of trade data to unexpected changes in product mix.

The gross shares of dry and refrigerated agri-food exports to Mexico are presented in Figure 2. The share of agri-food exports transported in refrigerated vehicles varies between $27 \%$ and $37 \%$ of total Canadian exports in recent years. 
Figure 1: Shares of Canadian Agri-food Exports to Mexico, 2003-2007

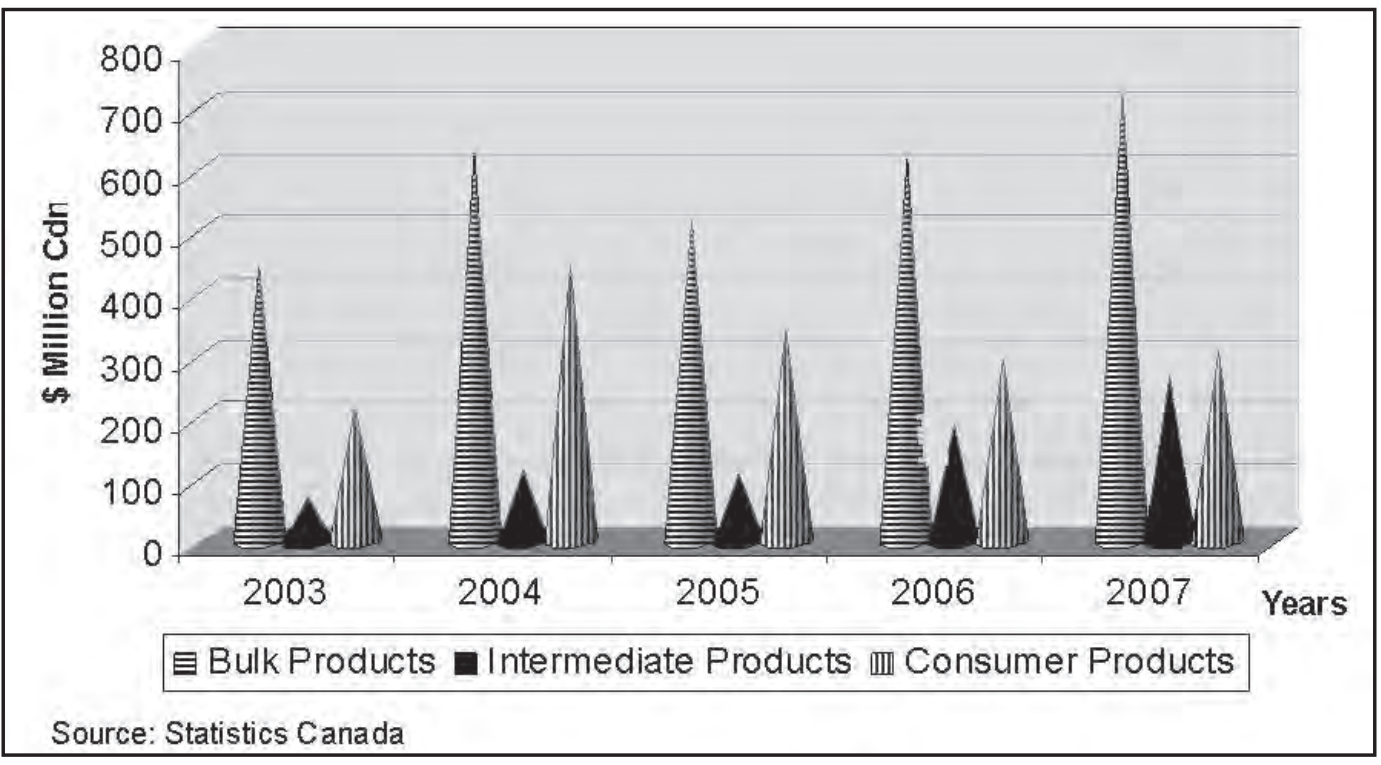

Figure 2: Shares of Agri-food Exports by Transport Requirements, 2003-2007

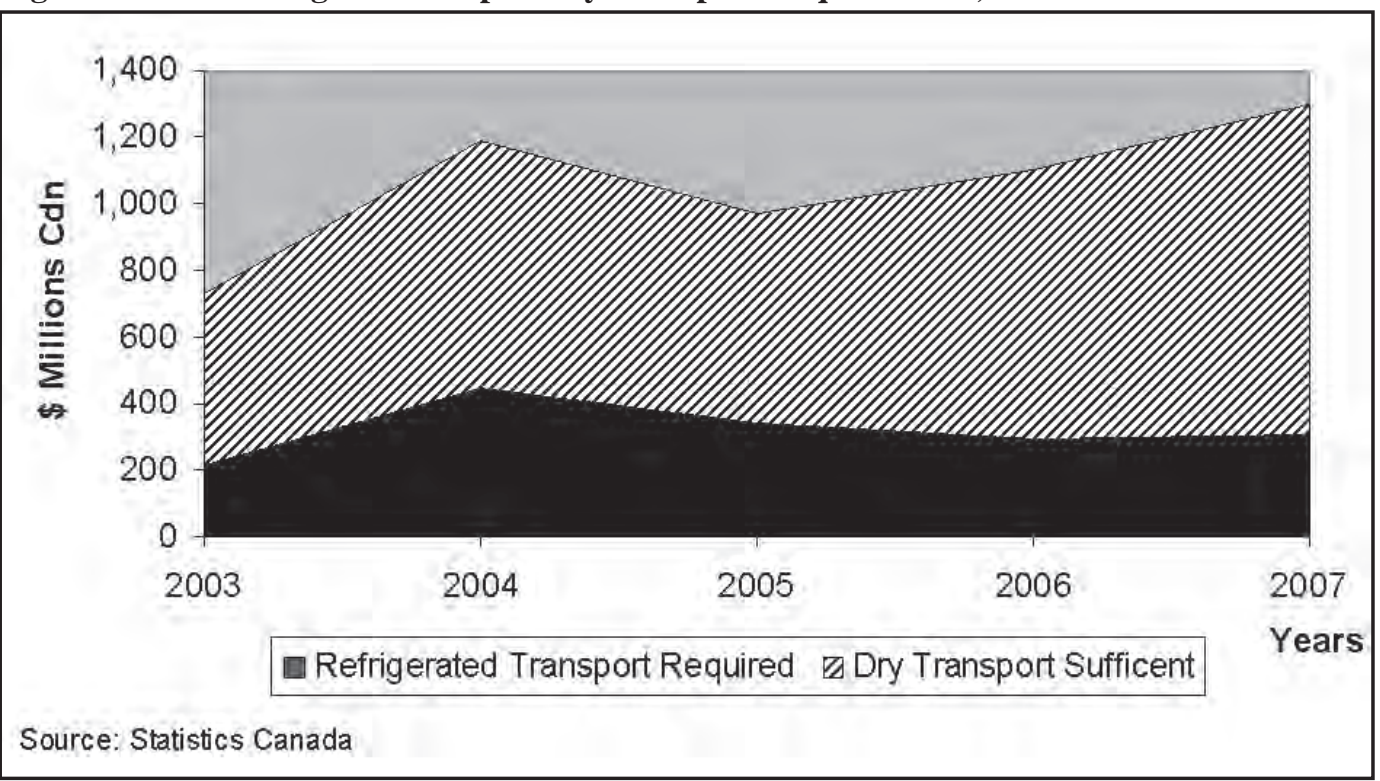

The four major perishable food product exports from Canada to Mexico are beef, pork, frozen French-fried potatoes and apples. Figure 3 illustrates the export values of these four products and the combined value of all others. Beef is the largest single food product export and continues to dominate Canadian exports despite the BSE problem. Pork has followed a trend similar to beef, but with less variation.

The residual category "other perishables" accounts for about one quarter of value-added food exports. These other perishables comprise a wide range of value-added agri-food products. During the course of this research interviews were conducted with exporters of frozen pizzas, English muffins, brownies, tarts, processed cod, fresh salmon and frozen hors d'oeuvres, as well as the major perishable commodity suppliers. 
Figure 3: Canadian Agri-food Exports to Mexico, Requiring Refrigerated Transport, 2003-2007

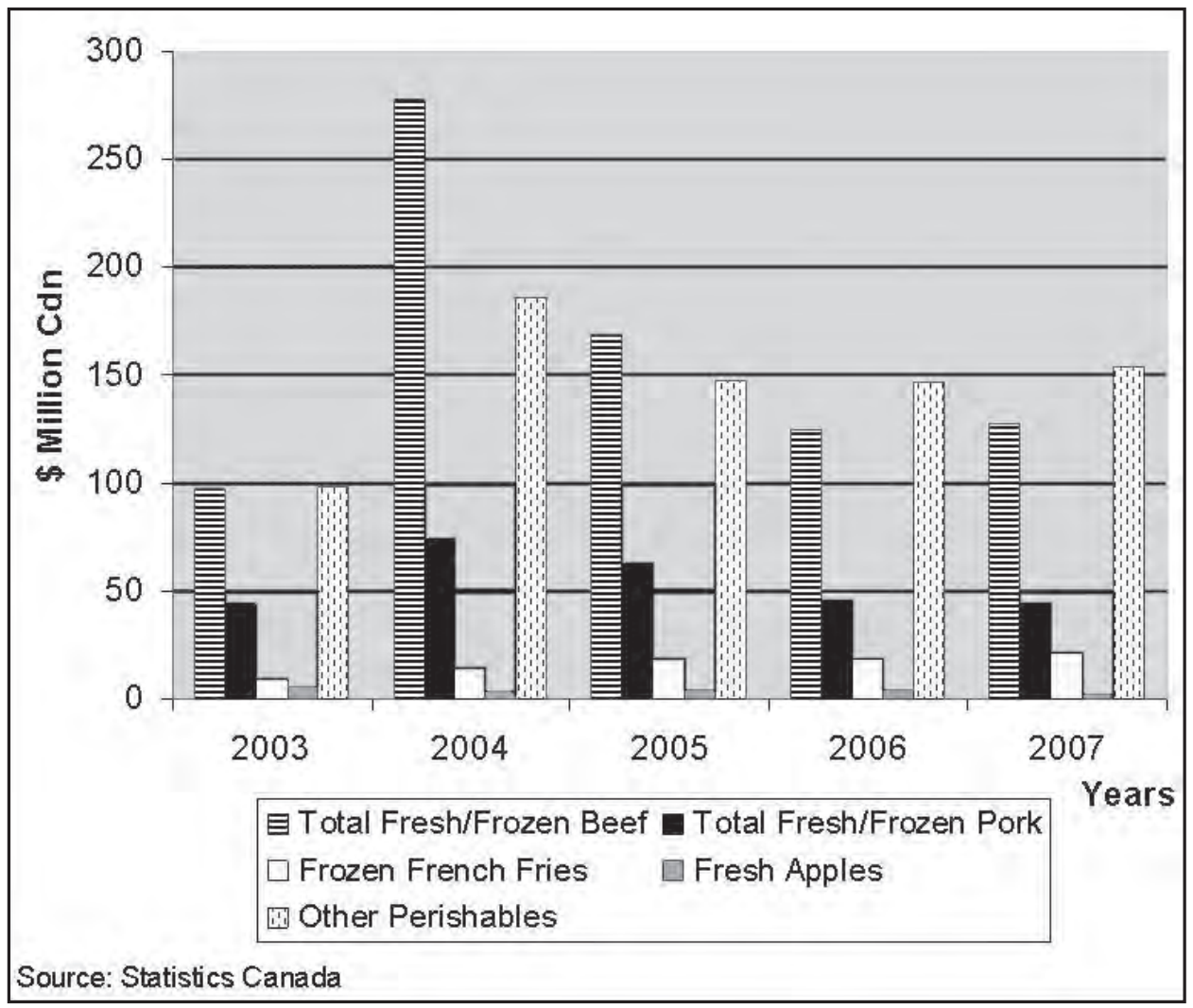

\section{TRANSPORTATION AND LOGISTICS SUPPLY OPTIONS}

The choice of transportation to use for exporting food products to Mexico depends on product shelflife, shipment size, service availability and cost. The costs of shipping perishables from Canada to Mexico are difficult to generalize because freight rates vary on a regional basis that reflects route miles and traffic density. Southbound trucking freight rates range from $\$ 2,500$ to $\$ 7,000$ depending on location, seasonal demand fluctuation and fuel surcharges. The cost of shipping a refrigerated railcar to Mexico is $\$ 11,000$ to $\$ 12,000$ per carload. Each railcar carries three to four times the truckload weight, which makes railcars less expensive on a ton-kilometer basis than trucking. A reliable range of freight rates for refrigerated marine containers could not be obtained, but their cost lies between truck and rail freight rates. Air cargo is limited to a few hub airports and costs from \$2 to $\$ 6$ per kilogram for shipment to Mexico City.

The following list summarizes in general terms the service options for Canadian food exporters.

- $\quad$ Fresh Products: 1 - 9 day shelf-life

- Air Cargo - 100 kilograms to 2 tons

- Fresh Products: 10 - 60 day shelf-life

- Refrigerated Tractor-trailers - 20 tons

- Refrigerated Less-than-truckload - up to 10 tons 
- Frozen Products: 2 - 24 month shelf-life

- Refrigerated Tractor-trailers - 20 tons

- Refrigerated Railcars - 85 tons

- Refrigerated Intermodal Containers - 20 tons

If the product has a very short shelf-life, then air shipment is the only choice. Typically, air shipments would range from 100 kilograms to one ton.

Fresh chilled products (not frozen) with a shelf-life from 10 to 60 days use refrigerated truck transport. These shipments are normally in full truckloads of approximately 20 tons. Refrigerated less-than-truckload (LTL) shipments are generally unavailable.

Frozen products have the most transportation choices because they enjoy the longest shelflife (up to 24 months) in transit and storage. Frozen goods are shipped in refrigerated trucks, railcars and intermodal sea containers. No Canadian railway offers refrigerated intermodal container services from Canada to Mexico.

Figure 4 presents the major transportation routes to Mexico. Although Mexico has many border crossings, Laredo dominates all entry points for non-grain deliveries to the principal markets in Mexico. Rail and truck compete mainly in the mid-continent corridor to source frozen beef, pork and French fries out of the Canadian prairies and for potato products out of Atlantic Canada. Processed and perishable products like apples are moved exclusively by truck, which also dominates the east and west coast routes. Marine transport competes with the railways for field crops and some frozen product.

Figure 4: Major Transportation Routes for Food Products Shipments from Canada to Mexico

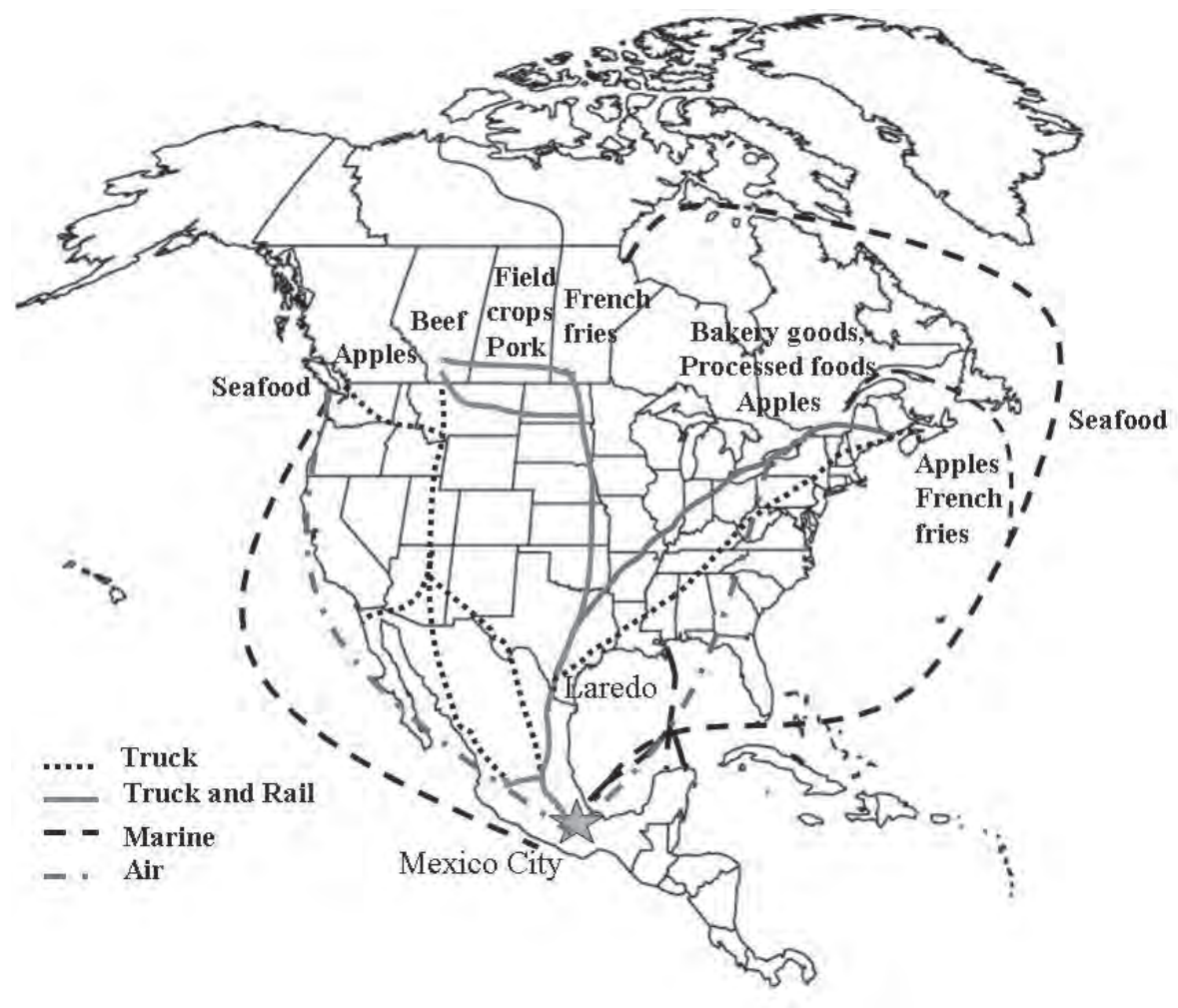


Air

Fresh food products are carried in intermodal air containers and in loose cargo of 100 to 150 kilograms. The air containers are the LD2 (0.95 ton) and the LD3 (1.25 ton). Loose cargo is shipped in the belly space of narrow-body airplanes, like the Boeing 737 and Airbus 320. Air freight containers are only carried on wide-body passenger aircraft or on dedicated cargo airplanes. Canada has only a few major gateways for containerized air freight to Mexico. At this time, no dedicated air cargo freighters serve the Canada-Mexico market. Containerized air cargo to Mexico City is available on passenger flights at Vancouver, Toronto and Montreal. Fresh fish is one of the few perishable food products that are shipped regularly via air from Canada to Mexico.

\section{Trucks}

Most Canadian food exporters use truckload shipments to serve the Mexican market. According to the Canadian shippers who were interviewed, trucks cost about $30 \%$ more than railcars on a per tonkilometer basis, but the transit time is shorter and the truckload unit size is less costly for inventory control and warehousing.

Refrigerated Canadian truck trailers can be interchanged with Mexican truckers that take the trailers into the interior of Mexico, and return the trailers to the Canadian carriers at the border. Alternatively, Canadian shipments can be trans-loaded at the U.S.-Mexican border. Goods can be emptied from a Canadian or American truck at a cross-dock facility directly into a Mexican trailer, or the goods can be placed in a refrigerated storage warehouse then re-loaded into a Mexican truck when one is available.

The trucking market is very competitive and dynamic. Exporters face a sellers' market in trucking services from September to December, and a buyers' market after Christmas. American trucks are permitted to pick up Canadian food products and carry them in-bond through the U.S. to the Mexican border crossings, but the cost of bonding has to be considered. The bond is like an insurance policy. The carriers have to pay about $\$ 1,500$ per year to carry a $\$ 50,000$ bond on their equipment. Unless the U.S. trucks are carrying a lot of Canadian volume, it may not be economically attractive for them to obtain the bonding insurance.

Several carriers offer LTL shipments for dry goods (non-refrigerated) from points in Canada to Laredo. During the course of this research, only one trucking company was identified that offers LTL refrigerated shipping to Mexico. In this case, the carrier demands a minimum 15-ton shipment that is not really an LTL service.

\section{Rail}

The rail systems in North America have a predominantly east/west orientation. Both CN Rail and CP Rail have U.S. subsidiaries and agreements with connecting railways to deliver railcars to Mexico. Nevertheless, the routing is not direct and interlining railcars adds to the total transit time. CP Rail hands off refrigerated railcars from western Canada to the U.S. railways for delivery to eastern Mexico at their St. Paul, MN interchange. Railcars from eastern Canada are handed off at Chicago. CN Rail can interline via its Illinois Central subsidiary with the Kansas City Southern for delivery to Mexico City. Both Canadian railways have agreements with the Burlington Northern Santa Fe (BNSF) and the Union Pacific (UP) railways for deliveries to Mexico.

Refrigerated railcars can be interlined with the Mexican railways for delivery to warehouses in Mexico City and other locations, but the ability to schedule through traffic depends on the commodity. Frozen French fries can be delivered by rail directly to Mexican receivers. Meat products must be inspected at the Mexican border. Border crossings without a rail-based meat inspection facility must unload frozen meat shipments into refrigerated warehouses. Subsequently, frozen beef and pork shipments are trucked to inspection stations and onward to their final destination in Mexico. 


\section{Marine Transport}

Some exporters have tried refrigerated marine containers, but none of the interviewed shippers use marine transport to eastern Mexico at the present time. The sea route is criticized as being slow and unreliable. Veracruz is the main Mexican container port on the Gulf of Mexico.

During the outbreak of BSE, when beef was not allowed to cross the United States, Canadian beef was shipped in refrigerated marine containers to Mexico via the west coast. Exporters have returned to refrigerated trucks and railcars now that passage through the United States is permitted again. Refrigerated container loads of frozen chicken and pork are exported through the Port of Vancouver to Manzanillo, Mexico, which is the largest container port on the Pacific coast. The freight forwarder who arranges these shipments reported that the marine route offers a cost benefit of $10 \%$ to $15 \%$ relative to truck rates.

Marine transport is used in the Gulf of Mexico to serve southern Mexico and the Yucatan Peninsula. A rail ferry that operates from Mobile, Alabama, to Coatzacoalcos, Mexico, takes about four days. This route is used by one of the frozen French fry importers to handle about $20 \%$ of their shipments.

\section{COLD CHAIN CHALLENGES}

Interview respondents outlined a number of challenges concerning the cold chain from Canada to Mexico. The logistical attributes of the cold chain to Mexico are considered first. Subsequently, modal challenges of the cold chain are examined for truck, air and rail transport.

\section{Maintaining Climate Control}

The quality of the cold chain is a function of technical capacity and management. The speed of a chemical reaction doubles with every $10^{\circ} \mathrm{C}$ increase in temperature. This is why holding the temperature of fresh foods close to zero extends their shelf-life.

The success of the cold chain depends on maintaining the temperature of the product within a very narrow range during transit through the marketing channel. Frozen products may withstand breaks in the cold chain better than fresh products, but shelf-life and quality are generally reduced by any unanticipated temperature increase. Consequently, shippers and carriers are cautious in choosing partners.

Respondent 3: Carrier - Truck. [Railway X] will ensure that the container is refueled and they will ensure that the setting is appropriate for the temperature, and so on. But, with [Railway Y], I would not interchange our reefers at this point. We don't know their procedures; we don't know what they are going to do.

At times, the cold chain of the Mexican distribution system can leave a lot to be desired. A refrigerated delivery truck that makes 10 deliveries over the course of its route is continually opening and closing its doors to ambient temperatures of about $25^{\circ} \mathrm{C}$. Under these conditions, the refrigeration unit has a hard time maintaining climate control.

Failure of the cold chain in Mexico is not just a technical issue.

Respondent 18: Importer of Frozen Products. The classic is the store manager, who to save energy, turns off all the electricity in the store every night and goes home. Don't turn off the freezers please!

The average quality of the cold chain in Mexico is lower than experienced in Canada or the United States, but the outlook is encouraging. The universal impression inferred from the study respondents in Mexico is that the cold chain has come a long way and is improving. As one respondent 
said, referring to a Mexican frozen warehouse and distribution firm, "They have excellent service, but it is not very cheap."

\section{Frozen versus Fresh}

Fresh products may spoil quickly if the refrigeration unit malfunctions or runs out of fuel. Fresh products depend on the speed of trucks and the driver to manage the refrigeration system. Aging in-transit benefits beef, but not pork, which is always tender and must be processed or used within 12 days of shipping. Truck drivers are expected to inspect and maintain the refrigeration unit every couple of hours.

Frozen goods are more forgiving of equipment failure in transit than are shipments of fresh chilled food products. An insulated railcar will keep the product frozen for a considerable period after the refrigeration unit shuts down. The railways have a good record for frozen shipments, but will not accept fresh products because they cannot guarantee quality.

Respondent 16: Carrier - Rail. We can move frozen product to and from Mexico but not refrigerated - because of the transit times and the equipment maintenance is very, very difficult. The temperature control on the equipment has to be constantly checked on the route. We are playing with other partners. There's at least two or three railroads involved. The risk [for fresh products] is too high.

\section{Inspection of Meat at the Border}

The inspection of meat at the border is necessary for both truck and rail shipments. Truck shipments are easier to handle at the border because they can pull up to the inspection facility's dock. At border crossings that lack rail meat inspection facilities, railcar shipments are stored in a refrigerated warehouse before movement to an inspection facility. The Kansas City Southern (KCS) railway is scheduled to open a refrigerated meat inspection facility in the summer of 2008 to eliminate the extra unloading/re-loading and warehousing charges (Eaton 2008).

Meat products have an expected break in the cold chain caused by border inspection, but any refrigerated product may be inspected or held up at the border. Fresh chilled products carry more risk than frozen foods.

Respondent 2: Exporter of Meat Products. With frozen, you still have the option-if something goes wrong with the paper - to put the load into cold storage and work on [the] papers, whereas with the fresh, you don't have that option. [For fresh], you are very much stressed out or things could go really wrong.

\section{Loading for the Border}

Some exporters may wish to load the truck from the floor up to avoid the cost and weight of pallets. However, if there is a border inspection, the break in the cold chain could make this a costly decision for perishable products.

Respondent 18: Importer of Frozen Products. When you get stopped in [Mexican] Customs, the inspector is going to say, "I need you to unload that trailer." And if you floor load it, it's going to take you a whole day to get your frozen product out and then back in, right? But if it's on a palette, the forklift comes, brings it out, the inspector sees it, okay, put it back in. Your cold chain was more or less intact and you're happy you didn't lose all your product. So, put it on palettes. 


\section{Loading for Handling}

Better quality of pallets and packaging are needed for shipping perishable products to Mexico. Transloaded cargo is handled more and the refrigerated environment picks up moisture from the atmosphere that can weaken packaging materials.

Respondent 11: Exporter of Fresh Chilled Products. Make sure packaging materials are good quality because in the end, cheap is expensive. We've seen that. We told one packer, "Listen, you've got to beef these boxes up, with corrugated cardboard because it's refrigerated, it's damp and the boxes will sag." He's trying to save a dollar but you don't with cheap pallets or packaging. Quality packaging is very important so it withstands the shipping, especially the transloading.

\section{Refrigerated Trucks}

The food distribution industry is set up to handle truckloads. The truckload order quantity provides sufficient volume to minimize average transportation costs and to avoid inventory stock-outs. Insufficient safety stocks can lead to expensive customer service failures. Distributors do not like stock-outs and discontinue supply sources that are unreliable. Truckload shipments permit exporters to maintain inventory for several items in their product line. When one item is selling faster than others, shipments can be mixed to refill the orders properly and maintain sufficient safety stocks.

Order processing cost is another reason for exporters to think in terms of truckload sizes. Customs brokers have fixed charges that could be as high as $\$ 500$ whether the shipment is a single pallet or a truck carrying 20 pallets. Volume is necessary to spread out these fixed logistics costs. The problem for new exporters is to build this volume of sales. For highly perishable goods, there may be no choice other than air freight, but if the product is reasonably storable (minimum 30 to 60 day shelf-life) the trade-off between warehousing costs in Mexico and trucking costs is the other option to consider.

Respondent 18: Importer of Frozen Products. Your biggest cost in this whole logistical process, it's not the handling, it's not the storage, storage is pretty big, but it's really just the shipping costs. If you can lower your transportation costs, you are going to save a lot of money. ... the more warehouses you have, the more ability you have to save on the shipping costs.

A public warehouse can receive and store full truckloads and make less-than-truckload deliveries to customers in Mexico. Public warehouses are also able to offer other services like inventory record maintenance for exporters.

Respondent 20: Distributor. We have nine distribution centers. When the product arrives at each one, they prepare the products for each store, restaurant, or hotel. In each distribution center, we have delivery trucks. In Cuautitlan, we consolidate product for the distribution center of Sam's Club.

Some Canadian shippers do not have sufficient demand to serve all Mexican markets, e.g. Tijuana, with truckload shipments. Some specialized product shippers can afford the cost of refrigerated LTL, but they prefer to move truckloads as much as possible. A shipper that can arrange more than 10 tons of freight may be better off to contract for a full truck.

Respondent 13: Exporter of Meat Products. It's difficult to find LTL refrigerated, but our type of business, we don't have a choice because we're not dealing in commodities. So, we live it everyday. ... To be cost effective, you have to fill up a [20-ton] truck as much as possible.

It was observed in Quebec that unrelated shippers do cooperate at times to share a full truckload service to Mexico. This is certainly less expensive, but it requires more coordination and flexibility in delivery times. Also, border crossing has greater risk of delays because there are more opportunities 
for document errors. The same problem confronts importers in Mexico that want to bring in small lots.

Respondent 24: Canadian Embassy Representative The other option [to air freight] would be to work with another importer here in Mexico and split the container but the Mexican importer says that is a little complicated because the timing has to be the same, the locations have to be the same, for example from Vancouver to Mexico.

Exporters develop relationships with carriers they can rely on. It takes only one break in the cold chain to destroy a high quality perishable product. Consequently, shippers are often reluctant to embrace offers of low rates from unknown carriers

Respondent 13: Exporter of Meat Products. There's a lot of guys that are fly-by-night. You're dealing with sensitive products that need temperature control and gas is expensive. They'll turn off the reefers, which has happened even to the best guys. Refrigeration is expensive and to keep the reefer going is costly. So, they shut it off for five, six, seven hours to save some money. Nobody knows the difference because they contract some of the work out. It's not necessarily their trucks they are running. It's dependent on a guy from "god-knows-where" and he's free for a week and needs a load.

\section{Air Freight}

Expensive products require a lower percentage of logistics costs per unit. Exporters of high-value products, like fresh seafood, can pass on the higher costs of air freight. This is not an option for most exporters, except for sending samples. If only a few pallets of product must go to Mexico to establish a market test, the cost of freight is just a market development expense. Only high-value goods are likely to be regular users of air freight to Mexico because of the freight costs, but shippers should not dismiss air freight too quickly. Other costs can be lower when air freight is used.

Respondent 9: Exporter of Refrigerated Products. One of the benefits of airlifting it is that you've bypassed all that rigmarole at Laredo. We were able to put a pallet load on the plane and these were sizable pallets and it was a sizable price, but they didn't have to pay the shipping either from Laredo to Mexico City. And, you are only crossing one border . . only dealing with one customs person, so there are some advantages to going by air.

A Canadian exporter of maple syrup products to Mexico was interviewed in this study. They do not require refrigeration and could use dry van LTL services, but found that air freight to Mexico City was more economical. Air freight eliminated some of the border hassles and experienced less breakage and shrinkage than truck transport.

Air freight shippers, which require refrigeration, use gel packs (mostly brine) that are frozen before shipping and packed with the fresh product. The gel packs add about $20 \%$ to the weight of the shipment but can hold the product in good condition under normal circumstances. Dry ice (solid carbon dioxide $\sim-78^{\circ} \mathrm{C}$ ) can also be used, but it is more difficult to control. Too much or placing it too close could damage fresh products.

The amount of cooling required to maintain quality fresh foods depends on the difference between the desired temperature and the ambient temperature. Exporters recognize the greater risk to ship to tropical countries than to temperate zones like Europe.

Respondent 28: Exporter of Fish Products. It would be different if I was sending something to a Scandinavian country, where the weather is not hot like it is in Mexico. Anytime you've got your perishable product that can't get released for a day or two, you always worry about that. So, as an exporter, you are always looking for temperate climates on perishable goods to be sending these products to. 
The length of time gel packs can hold the product in good condition is much shorter in the ambient temperatures encountered in the tropical countries.

Air cargo on passenger airlines presents the risk that the volume of baggage that is given first priority will exceed the capacity designated for it. If the flight fills up, the perishable commodity may be forced to wait for another flight. In general, the airlines are very attentive in expediting perishables, but the gel packs will only last so long, especially in hot temperatures.

\section{Refrigerated Railcars}

Refrigerated railcar service to Mexico is generally difficult to obtain from everywhere in Canada. Refrigerated equipment is expensive, and the railways are reluctant to purchase an additional vehicle unless they can be assured it will be employed. The railways actively encourage large shippers to purchase or lease refrigerated railcars to carry their goods. The railways manage their own fleets aggressively.

Respondent 16: Carrier - Rail. From a railroad perspective, we don't like to let refrigerated railcars take a long cycle time because they're not earning money for us. We actually sit on top of those cars with a whip and push them down. We'll ride them because it costs us a lot of money to have them sitting on someone else's lines. It's a huge investment. The railroads don't like to have any cars idle but if we are going to have any equipment idle we don't want it to be refrigerated cars.

The railways' maximum charges are constrained by the rates offered to shippers by refrigerated trucks. Refrigerated trucks have the advantage of triangulation in competing with the railway. Whereas a railcar is confined to its tracks and more or less retraces its route, a truck can run empty from Laredo, TX, to Arizona to pick up a northbound load of fresh produce. If the railway costs are not assisted by a backhaul load, they are forced to seek the round-trip costs from Canadian exporters.

Thin margins leave scant incentive for the Canadian railways to improve service to the Mexican market. Exporters to Mexico have to compete for refrigerated railcars with the more lucrative routes in Canada. If the railway can obtain quicker cycle times for its equipment on east/west routes, then it is difficult to convince them to divert their cars to north/south routes.

Refrigerated equipment is more delicate, more valuable and more management-intensive than dry vans and boxcars. The purchase price of a refrigerated intermodal container or truck trailer is $\$ 65,000$ to $\$ 70,000$ more than a dry van. If a dry van has a small leak, it is easier to fix than a break in the insulated envelope of a refrigerated trailer. Moreover, a leak in a dry van may do little damage to the cargo, while a loss of refrigeration is almost guaranteed to affect the quality of perishable products. The delicate nature of refrigerated equipment and its costs are the prime reasons that the railways are not interested in providing refrigerated intermodal container services to Mexico.

\section{Recommendations - Cold Chain Issues}

- $\quad$ Abuse of the cold chain may lie outside the exporter's control, but the consumer knows only what the product is like at the far end of the supply chain. Consequently, exporters should periodically test the quality of their products at the retail sales point and search for "cold supply chain" breaches. Quality monitoring can be done via supply chain partners with the use of relatively inexpensive in-transit temperature monitoring equipment.

- $\quad$ Packaging and pallet quality is important for exporting refrigerated products to Mexico. Pallets must be fumigated and food grade quality. Handling materials must be able to withstand the damp environment of the refrigerated trailer and facilitate rapid unloading, inspection and trans-loading. Lower-quality packaging can be a "penny wise, pound foolish” strategy. 
- $\quad$ Longer-term arrangements with both trucking firms and cold storage warehouses are advisable because spot market arrangements can be difficult during periods of high demand for limited reefer and cold storage capacity.

- The cost of shipping railway boxcars of frozen meat to Mexico may be reduced when a refrigerated railcar meat inspection facility opens at the U.S.-Mexico border for rail shipments. This could help reduce the southbound rail shipping costs, but it will also aggravate the imbalance of refrigerated rail traffic. At the moment only a quarter of the available northbound refrigerated rail cars find loads in Mexico.

\section{CONCLUSIONS}

The success of the value-added food sector is premised on a reliable cold chain for transport and distribution. The cold chain to Mexico has more opportunities for breaks to occur than Canada-U.S. trade. Every time there is inspection, trans-shipment or equipment interline, the integrity of the cold chain is tested.

Refrigerated trucks are the most widely used mode of transport for the export of fresh chilled and frozen food products to Mexico. Air transport is used for highly perishable, luxury food products and the transport of samples. Refrigerated railway boxcars are used only when the product is frozen and the volume is sufficient to utilize their capacity. Marine transport has a minor role in frozen food shipments.

Refrigerated product trade between Canada and Mexico is very unbalanced. This creates the problem of empty backhauls. The lack of northbound return loads is a key problem in using refrigerated railway boxcars. If Canadian shippers could partner with Mexican shippers to balance refrigerated movements, freight costs for both parties could be reduced and the railways would show more interest in providing equipment.

It is unclear why the railways have such difficulty sourcing northbound loads for refrigerated cars in Mexico. The state of refrigerated rail transport in Mexico warrants further study.

\section{References}

Agriculture and Agri-food Canada “Agri-Food Country Profile Mexico.” May 2006. http://www.ats. agr.gc.ca/latin/3991_e.htm

Eaton, David. Director, Corporate Affairs and Right of Way Protection, Kansas City Southern de Mexico. (Personal interview, March 2008).

Eisenhardt, Kathleen M. "Building Theories from Case Study Research.” Academy of Management Review 14(4), (1989): 532-550.

Locke, Karen D. Grounded Theory in Management Research. Sage Publications, Thousand Oaks, California, 2001.

Prentice, Barry E. and Ron McLachlin. "Refrigerated Transport of Canadian Agri-Food Products to Mexico: Benchmarks and Best Practices.” Prepared for Agriculture and Agri-Food Canada and the Provincial Agriculture Departments, July 2007. http://www.ats.agr.gc.ca/info/lac-e htm\#Mexico

Statistics Canada. Agri-food Trade Statistics, http://www.ats.agr.gc.ca/stats/Mexico_x_e.pdf

Strauss, Anselm L. and Juliet Corbin. Basics of Qualitative Research: Techniques and Procedures for Developing Grounded Theory. 2nd edition, Sage Publications, Thousand Oaks, California, 1998. 
Yin, Robert K. Case Study Research: Design and Methods. 3rd edition, Sage Publications, Thousand Oaks, California, 2003.

Barry E. Prentice is a professor of supply chain management at the University of Manitoba, Asper School of Business, and the former director (1996-2005) of the Transport Institute. His major research and teaching interests include logistics, transportation economics, urban transport and trade policy. Prentice has authored or co-authored more than 250 research reports, journal articles and contributions to books. In 1999, National Transportation Week named him Manitoba Transportation Person of the Year. He has served as a member of several transportation boards of directors, task forces and expert committees. In 1997-98, he was president of the Canadian Transportation Research Forum.

Ron McLachlin is an associate professor of operations management at the University of Manitoba, Asper School of Business. He is interested in process innovation, the implementation of supply chain integration, and supply chain postponement strategies. He is currently researching supply chain management for the not-for-profit sector in interrupted environments. His publications are in the Journal of Operations Management, International Journal of Manufacturing Technology and Management, Management Decision, Operations Management Review, Managing Service Quality, Business Quarterly, and Elsevier Science Publishers. He is an associate editor of the Journal of Operations Management. 